\title{
ARAŞTIRMA / RESEARCH \\ Comparison of ultrasound-guided femoral + anterior sciatic nerve block and genicular nerve block for postoperative pain in total knee arthroplasty
}

Total diz artroplastisinde postoperatif ağr1 için ultrason eşliğinde femoral + anterior siyatik sinir bloğu ve geniküler sinir bloğunun karşılaştırılması

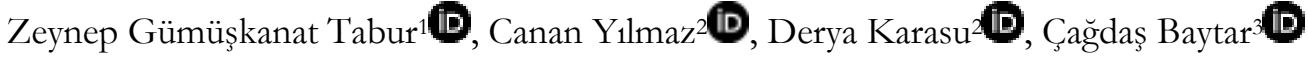

${ }^{1}$ Bursa City Hospital, Department of Anesthesiology and Reanimation, Bursa, Turkey

${ }^{2}$ Health Sciences University, Bursa Yuksek Ihtisas Training and Education Hospital, Dept of Anesthesiology and Reanimation, Bursa, Turkey

${ }^{3}$ Zonguldak Bülent Ecevit University Faculty of Medicine, Dept of Anesthesiology and Reanimation, Zonguldak, Turkey

\begin{abstract}
Purpose: This study aimed to compare the effectiveness of ultrasound-guided femoral and anterior sciatic (FAS) nerve blocks and genicular $(\mathrm{G})$ nerve blocks as preventive analgesia methods after total knee arthroplasty.

Materials and Methods: Fifty patients, aged $55-80$ years were divided into two groups preoperatively. Patients in the FAS group $(\mathrm{n}=25)$ received $20 \mathrm{~mL}$ solutions $(10 \mathrm{~mL}$ $0.5 \%$ bupivacaine, $1 \mathrm{~mL}[4 \mathrm{mg}]$ dexamethasone, and $9 \mathrm{~mL}$ saline) in both femoral and sciatic blocks. Patients in the $\mathrm{G}$ group $(\mathrm{n}=25)$ received $5 \mathrm{~mL}$ solutions $(2 \mathrm{~mL} \quad 0.5 \%$ bupivacaine, $1 \mathrm{~mL}$ [ $4 \mathrm{mg}$ ] dexamethasone, and $2 \mathrm{~mL}$ saline) for each nerve. Patients were assessed $24 \mathrm{~h}$ postoperatively, and pain scores, time to first analgesic requirement, total analgesic dose, and postoperative complications during the first $24 \mathrm{~h}$ were recorded.

Results: VAS scores at postoperative 0,1 , and $6 \mathrm{~h}$ and the total amount of tramadol consumed $24 \mathrm{~h}$ were lower in the FAS group than in the $\mathrm{G}$ group. There was no requirement for additional analgesia in the first $24 \mathrm{~h}$ in the FAS group; however, 9 patients required additional analgesia in the $G$ group.

Conclusion: USG FAS nerve blocks were superior to the genicular nerve blocks in TKA. Additionally, the genicular block doesn't cause motor block. A genicular block can be considered as an alternative with this regard.
\end{abstract}

Cukurova Medical Journal 2021;46(4):1433-1440

Keywords: Ultrasonography, sciatic nerve, total knee arthroplasty, postoperative pain
Öz

Amaç: Çalışmamızın amacı; genel anestezi altında yapılan total diz artroplastisinde (TDA) ultrason eşliğinde uygulanan femoral ve anterior siyatik (FAS) sinir bloğu ile geniküler $(G)$ sinir bloğunun postoperatif analjezik etkilerini araştırmaktır.

Gereç ve Yöntem: Ameliyat öncesi 55-80 yaş arası toplam 50 hasta 2 gruba ayrildı. FAS gruptaki hastalara $(n=25) 20$ $\mathrm{ml}$ solüsyon $(10 \mathrm{ml} \% 0.5$ Bupivakain $+1 \mathrm{ml}(4 \mathrm{mg})$ Deksametazon $+9 \mathrm{ml}$ serum fizyolojik) ultrason eşliğinde hem femoral hem de siyatik blok uygulamak için uygulandi. $\mathrm{G}$ gruptaki hastalara $(\mathrm{n}=25)$ her bir geniküler sinire $5 \mathrm{ml}$ solüsyon (2 $\mathrm{ml} \% 0.5$ Bupivakain $+1 \mathrm{ml}(4 \mathrm{mg})$ Deksametazon $+2 \mathrm{ml}$ serum fizyolojik) geniküler blok için ultrason eşliğinde uygulandı. Hastaların postoperatif 24 saat boyunca ağrı skorları, tüketilen opioid miktarları, ilk analjezik gereksinim zamanlar1, postoperatif komplikasyonları kaydedildi.

Bulgular: Postoperatif 0, 1, ve 6. saatteki VAS skorlar1 ve postoperatif 24 saat boyunca tüketilen tramadol miktarı FAS grubunda $G$ grubuna göre anlamlı olarak daha düşük bulundu. Operasyon sonrası FAS grupta hiç ek analjezik gereksinimi olmazken, G grubunda 9 hastada ek analjezik ihtiyacı oldu.

Sonuç: Ultrason eşliğinde uygulanan femoral ve siyatik sinir blokları TDA'da geniküler sinir bloklarından üstündü. Ayrıca geniküler bloğun motor bloğa neden olmamasıyla TKA'da postoperatif analjezi amaciyla alternatif olarak kullanilabilecektir

Anahtar kelimeler: Ultrasonografi, siyatik sinir bloğu, total diz artroplastisi, postoperatif ağr1 


\section{INTRODUCTION}

Knee osteoarthritis is a disease frequently seen in middle-aged patients and causes physical and psychosocial morbidity if treated inappropriately ${ }^{1}$. Severe knee osteoarthritis is currently the most common indication for total knee arthroplasty $(\mathrm{TKA})^{2}$.

Despite improved surgical techniques, more than $50 \%$ of patients experience moderate or severe postoperative pain ${ }^{3,4}$. To provide multimodal analgesia for TKA, oral non-steroidal antiinflammatory drugs (NSAIDs), intravenous (IV) corticosteroids, local anesthetic infiltration instead of incision, intraarticular catheter applications, intraoperative periarticular injections, and preoperative and postoperative central and peripheral nerve blocks have been defined. It is aimed at providing better analgesia with an appropriate combination of these methods 5 .

Neuraxial blocks are frequently used for analgesia and anesthesia in TKA. However, central neuraxial blocks have serious side effects such as motor block, urinary retention, hypotension, nausea, vomiting, and patched block ${ }^{6}$. Thus, peripheral nerve blocks are preferred to avoid these side effects. Peripheral nerve blocks, such as femoral and sciatic nerve blocks, are frequently preferred for postoperative pain after $\mathrm{TKA}^{7}$. A genicular block is an up-to-date method applied with fewer medications, without forming a motor block for postoperative pain in $\mathrm{TKA}^{8}$. Our hypothesis is that genicular block, which does not cause motor block, may be an alternative to the femoral+sciatic block combination preferred for analgesia after total knee replacement.

This study aimed to compare the efficacy of ultrasound-guided (USG femoral and anterior sciatic nerve blocks and genicular block as preventive analgesia methods after TKA.

\section{MATERIALS AND METHODS}

The study protocol was approved by the local ethics committee (Faculty of Medicine Clinical Research Ethics Committee, Ethical number: 2017-17/31). Written informed consent was obtained from each patient, and the study was conducted in accordance with the principles of the Declaration of Helsinki. This was a single-center, prospective, randomized, observer-blinded study at University of Health Sciences, Bursa Yüksek İhtisas Training and Research Hospital in Turkey.

\section{Sample}

The study included 58 patients (aged 55-80 years, American Society of Anesthesiologists score I-III, general anesthesia) who were scheduled for unilateral primary TKA due to primary varus knee osteoarthritis. Eight patients were excluded from the study because of language problems, COPD and other reasons (Figure 1). Exclusion criteria were mental disorders, allergy to the drugs used, infection in the area where the block was to be applied, bleeding diathesis, body mass index (BMI) $>35 \mathrm{~kg}$ $\mathrm{m}-2$, or inability to communicate. Fifty patients were randomly divided into two groups using sealed and opaque envelopes were prepared using a computer program before starting the study by a researcher who was not included in the study: group femoral and sciatic block (FAS) $(n=25)$ and group genicular block $(\mathrm{G})(\mathrm{n}=25)$.

\section{Pre-block preparation}

Premedication was administered to all patients in the operating room (0.01-0.02 mg kg-1 IV midazolam), and routine monitoring was performed. Peripheral blocks were performed using a single USG $\left(\right.$ Esaote $^{\circledR}$, MyLab30Gold Cardiovascular, Florence, Italy) after sedation before general anesthesia. All blocks were performed by the same experienced anesthesiologists (ZT and $\mathrm{CB})$.

\section{Femoral and anterior sciatic block procedure}

Femoral block procedure: In the FAS group $(\mathrm{n}=22)$, the femoral block was performed after the patient was sedated in the supine position. The thigh was slightly abducted. The patient was positioned on the ipsilateral hand, under his head. After the skin was adequately sterilized, a sterile-coated high-frequency $(12-13 \mathrm{MHz})$ linear USG probe was placed under the inguinal fold, parallel to the inguinal ligament. First, the femoral artery pulse and then the femoral vein in the medial of the artery were determined on a shortaxis ultrasonographic image. The femoral nerve was visualized in the sulcus of the iliopsoas muscle under the fascia iliaca, lateral to the femoral artery, hyperechoic oval, or triangular shape. Skin infiltration 
was performed using $1-2 \mathrm{~mL}$ of $2 \%$ lidocaine to induce local anesthesia at the injection point. After the neurostimulator was set to $1-1.5 \mathrm{~mA}, 0.1 \mathrm{~ms}, 1$ $\mathrm{Hz}$, it was entered into the skin at a $45-60^{\circ}$ angle using the in-plane technique with the block needle. The block needle $(150 \mathrm{~mm}, 20$ gauge, Stimuplex Ultra, B Braun, Melsungen AG, Germany) was directed toward the lateral and cephalized. After the rhythmic twitch (patellar dance) movement in the characteristic patella was observed to continue at $0.3-$ $0.5 \mathrm{~mA}$ current, a total of $20 \mathrm{~mL}$ solution prepared using $10 \mathrm{~mL} \quad 0.5 \%$ bupivacaine, $1 \mathrm{~mL}$ (4 mg) dexamethasone, and $9 \mathrm{~mL}$ saline was applied with a negative aspiration test.

Anterior sciatic block procedure: While the patient was in the supine position, the hip and knee were flexed slightly to give the hip a $45^{\circ}$ external rotation. A sterile-coated low-frequency (3-5 MHz) convex USG probe was placed transversely approximately 10 $\mathrm{cm}$ distal to the inguinal ligament and medial to the thigh. After the sciatic nerve was visualized using a hyperechoic flat in the medial femur, a block needle (150 mm, 20 gauge, Stimuplex Ultra, B Braun, Melsungen AG, Germany) was directed using the inplane technique. The sciatic nerve was reached at a depth of approximately $10-12 \mathrm{~cm}$. When the contraction movement continued at $0.3-0.5 \mathrm{~mA}$ current in the calf, foot, or thumb, following the negative aspiration test, a total of $20 \mathrm{~mL}$ solution was administered in the form of $10 \mathrm{~mL} 0.5 \%$ bupivacaine, $1 \mathrm{~mL}(4 \mathrm{mg})$ dexamethasone, and $9 \mathrm{~mL}$ saline.

\section{Genicular block procedure}

In the $G$ group (n:24), superior medial genicular nerve (SMGN), superior lateral genicular nerve (SLGN), and inferior medial genicular nerve (IMGN) of each patient were blocked together. The patient was admitted to the supine position, and the knee to be operated on was slightly flexed. A block needle (22 gauge, $50 \mathrm{~mm}$; Stimuplex Ultra, B. Brun Melsungen AG, Germany) was directed to the three nerves using a high-frequency $(12-13 \mathrm{MHz})$ linear USG probe. After the negative aspiration test, a total of $5 \mathrm{~mL}$ solution in the form of $2 \mathrm{~mL} \% 0.5$ bupivacaine, $1 \mathrm{~mL}$ (4 mg) dexamethasone, and $2 \mathrm{~mL}$ saline was injected for each branch of the genicular nerve. For the SMGN block, the femoral medial epicondyle and adductor tubercle were visualized. A superior medial genicular artery was observed between the two structures. The block needle was directed $1 \mathrm{~cm}$ away from the bone until it approached the artery, and the solution was administered. For the IMGN block, the distal tibial medial epicondyle and medial collateral ligament of the tibia were determined. The inferior medial genicular artery was visualized between the two structures, and the solution was administered around the artery. For the SLGN block, the lateral epicondyle of the femur and distal edge of the vastus lateralis was visualized. The superior lateral genicular artery was visualized between these structures, and the solution was administered around the arterial area.

\section{Anesthesia management}

After the blocks were performed, all patients were intubated following anesthesia induction using 1-2 mg kg-1 fentanyl, 1.5-2 mg kg-1 propofol, and 0.6 $\mathrm{mg} \mathrm{kg-1}$ rocuronium. Sevoflurane was used to maintain anesthesia at a rate of $2 \mathrm{~L} / \mathrm{min}$ in a $50 \%$ air $/ 50 \%$ oxygen mixture with a minimum alveolar concentration of 1 . Intraoperatively, additional drug doses were administered, as needed.

\section{Analgesia management}

All patients were administered $75 \mathrm{mg}$ diclofenac sodium intramuscular (IM) before the operation and $1 \mathrm{~g}$ paracetamol IV at the end of the operation. For postoperative pain control, an IV patient-controlled analgesia (PCA) device (CADD-Legacy PCA, Smiths Medical, St Paul, MN, USA) was prepared with an IV solution of $72 \mathrm{~mL}$ saline and $8 \mathrm{~mL}$ tramadol (50 $\mathrm{mg} / \mathrm{mL}$ ). Without basal infusion and loading dose, the bolus dose was set to $5 \mathrm{~mL}$, with a lock-out time of $20 \mathrm{~min}$. All patients received $1 \mathrm{~g}$ of paracetamol IV every $8 \mathrm{~h}$ after surgery. Despite these, $75 \mathrm{mg}$ IM diclofenac sodium was administered as rescue analgesia for patients with visual analog scale (VAS) $>5$.

\section{Outcomes}

The primary outcomes included pain scores and the consumption of rescue analgesics. The pain was evaluated based on the resting VAS score. Another anesthesiologist evaluated VAS scores at $0,1,6,12$, and $24 \mathrm{~h}$. In addition, tramadol consumption and the use of another rescue analgesia were recorded by the same anesthesiologist for $24 \mathrm{~h}$. Secondary outcomes included hemodynamic parameters (blood pressure $>140 / 90$ mmHg: hypertension, blood pressure <90/60 mmHg: hypotension, heart rate >100/min: tachycardia, heart rate $<60 / \mathrm{min}:$ bradycardia); 
intraoperative (hypo-hypertension, bradycardiatachycardia); and postoperative (stammering, nauseavomiting, agitation, and tinnitus) side effects; Bromage scores; and patient-surgeon satisfaction (very satisfied, satisfied, undecided, and not satisfied).

\section{Statistical analysis}

The approximate sample size was calculated before the study using Power Analysis and Sample Size-11 software (NCSS statistical software, Kaysville, Utah, USA). The minimum number of patients was found to be totally 36 in the sample size analysis performed as per the study conducted by Qudsi-Sinclair et al. ${ }^{9}$, with a $95 \%$ confidence interval and $80 \%$ power.

Statistical analysis was performed using SPSS version 22 (IBM Corporation, Armonk, NY, USA) for Windows (Microsoft Corporation, Redmond, WA, USA). In the descriptive statistics, quantitative data are expressed as mean \pm standard deviation (SD), and median, interquartile range. Qualitative data are expressed as percentages (\%). Conformity to normal distribution was assessed using the Shapiro wilk test. For data not exhibiting normal distribution, the Mann Whitney U-test, Kruskal-Wallis test, and the chi-squared test were used; $\mathrm{p}<0.05$ was considered statistically significant.

\section{RESULTS}

Of the 58 patients who underwent TKA, 50 were included in the study, and 46 patients (three patients were excluded from the study due to problems with PCA and one patient with USG probe problems) were evaluated statistically (Fig 1). No statistically significant difference was found between the groups, when the demographic data of the patients were examined (Table 1).

The duration of surgery and tourniquet were significantly longer in the $G$ group ( $p=0.041$ and 0.047 , respectively) (Table 2).

No statistically significant difference was found between the groups regarding intraoperative opioid consumption and block application time $(\mathrm{p}>0.05$, Table 2).

VAS scores in the FAS group were significantly lower than those in the G group at 0,1 , and $6 \mathrm{~h}(\mathrm{p}<0.001$, $\mathrm{p}<0.001$, and $\mathrm{p}<0.001$, respectively; Table 3 ).

The patients were followed up for a period of $24 \mathrm{~h}$ regarding PCA device use. The patients' request, the number of analgesic doses delivered by the PCA device, and the total amount of tramadol consumed were significantly higher in the G group ( $p<0.001$, $p$ $<0.001$, and $\mathrm{p}<0.001$, respectively; Table 4). Moreover, the first analgesic time was also significantly shorter in the $G$ group $(p<0.001$, Table 4). There was no requirement for additional analgesia in the first $24 \mathrm{~h}$ in the FAS group; however, nine patients required additional analgesia in the $G$ group $(\mathrm{p}=0.03)$.

Table 1. Demographic and clinical data

\begin{tabular}{|l|c|c|c|}
\hline & FAS Group (n=22) & G Group (n=24) & p \\
\hline Age (years) & $69.50 \pm 7.14$ & $67.29 \pm 7.43$ & 0.311 \\
\hline $\mathrm{Sex}^{\#}(\mathrm{M} / \mathrm{F})$ & $3 / 19$ & $5 / 19$ & 0.702 \\
\hline $\mathrm{BMI}^{\#}\left(\mathrm{~kg} / \mathrm{m}^{2}\right)$ & $31.93 \pm 3.46$ & $32.21 \pm 2.50$ & 0.326 \\
\hline $\mathrm{ASA}(\mathrm{I} / \mathrm{II} / \mathrm{III})$ & $0 / 22 / 0$ & $0 / 24 / 0$ & \\
\hline
\end{tabular}

ASA: American Society of Anaesthesiologists, BMI: Body Mass Index, FAS: Femoral + Sciatic, G: Genicular, M: Male, F: Female, \#: Mean \pm Standart Deviation

Table 2. Fentanyl consumption, duration of surgical procedure and tourniquet, block application time

\begin{tabular}{|l|c|c|c|}
\hline & FAS Group (n=22) & G Group (n=24) & p \\
\hline Fentanyl\#(mcg) & $111.36 \pm 21.44$ & $118.75 \pm 24.72$ & 0.282 \\
\hline Duration of surgical procedure \# (min) & $110.91 \pm 33.51$ & $131.54 \pm 32.76$ & $0.041^{*}$ \\
\hline Duration of tourniquet (min) & $92.43 \pm 20.05$ & $109.30 \pm 15.71$ & $0.047^{*}$ \\
\hline Block application time (min) & $17.68 \pm 2.37$ & $16.46 \pm 2.02$ & 0.607 \\
\hline
\end{tabular}

FAS: Femoral+Sciatic G: Genicular \#: Mean \pm Standart Deviation *:p $<0.05$ 
Table 3. VAS Pain scores

\begin{tabular}{|l|c|c|c|}
\hline VAS & FAS Group (n=22) & G Group (n=24) & p \\
\hline 0.hour & $1(0-3) \#$ & $3(0-5) \#$ & $<0.001^{*}$ \\
\hline 1.hour & $1(0-3) \#$ & $4(0-6) \#$ & $<0.001^{*}$ \\
\hline 6.hour & $1.50(0-4) \#$ & $3(2-5) \#$ & $<0.001^{*}$ \\
\hline 12.hour & $2(1-3) \#$ & $2(1-4) \#$ & 0.624 \\
\hline 24.hour & $2(0-3) \#$ & $2(0-4) \#$ & 0.358 \\
\hline
\end{tabular}

FAS: Femoral+sciatic, G: Genicular, VAS:Visual Analog Scale \#: Median (Minimum-Maksimum), *:p<0.05

Table 4. Comparison of patient controlled analgesia in groups

\begin{tabular}{|l|c|c|c|}
\hline PCA & FAS Group $\mathbf{( n = 2 2 )}$ & G Group (n=24) & p \\
\hline Total bolus $¥$ & $8.50(6-12)$ & $13(10-16)$ & $<0.001^{*}$ \\
\hline Total request $¥$ & $9.50(6-13)$ & $13.50(10-16)$ & $<0.001^{*}$ \\
\hline First analgesic time $^{\#}(\mathrm{~min})$ & $578.4 \pm 141.6$ & $157.8 \pm 102.6$ & $<0.001^{*}$ \\
\hline Tramadol consumption $24 \mathrm{~h}^{\#}(\mathrm{mg})$ & $211.36 \pm 43.45$ & $327.08 \pm 40.32$ & $<0.001^{*}$ \\
\hline
\end{tabular}

PCA: Patient controlled analgesia, FAS: Femoral+Sciatic, G: Genicular, \#:Mean+Standard deviation, n (\%), ¥: Median (MinimumMaksimum), ${ }^{*}$ p $<0.05$

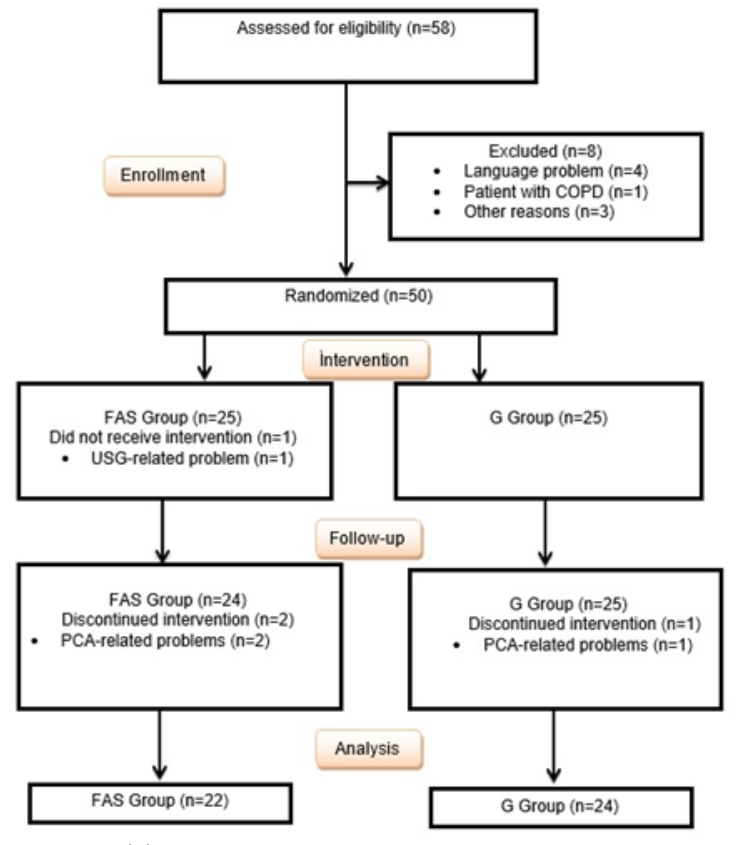

Figure 1. Trial flow chart

No statistically significant difference was found between the groups in terms of heart rate and mean blood pressure $(\mathrm{p}>0.05)$. Bromage scores were significantly higher in the FAS group at $0,1,6$, and $12 \mathrm{~h}(\mathrm{p}<0.05$, Table 5).

No statistically significant differences were found in intraoperative complications between the groups $(\mathrm{p}>$ 0.05). In the comparison of postoperative complications, nausea and vomiting were recorded in three patients in the FAS group and six in the $G$ group, and hypertension was observed in one patient in the $G$ group ( $p>0.05)$. Patient satisfaction was reported as very satisfied by 14 , satisfied by seven, and undecided by one of the 22 patients in the FAS group, and very satisfied by 13 , satisfied by nine, and undecided by two of the 24 patients in the G group. No statistically significant difference regarding patient and surgeon satisfaction was found between the groups $(\mathrm{p}>0.05)$. 
Table 5. Bromage scores

\begin{tabular}{|l|c|c|c|}
\hline Length of follow-up & FAS Group (n=22) & G Group (n=24) & p \\
\hline 0.hour\# & $2(1-2)$ & $0(0-0)$ & $<0.001^{*}$ \\
\hline 1.hour\# & $1(0-3)$ & $0(0-0)$ & $<0.001^{*}$ \\
\hline 6.hour\# & $1(0-2)$ & $0(0-0)$ & $<0.001^{*}$ \\
\hline 12.hour\# & $0(0-1)$ & $0(0-0)$ & 0.64 \\
\hline 24.hour\# & $0(0-0)$ & $0(0-0)$ & 1 \\
\hline
\end{tabular}

FAS: Femoral+sciatic, G: Genicular, \#: Median (Minimum-Maksimum), *:p $<0.05$

\section{DISCUSSION}

This prospective, randomized, observer-blinded study compared FAS and genicular nerve blocks for preventive analgesia in 46 patients who underwent unilateral primary TKA under general anesthesia. VAS scores at postoperative 0,1 , and $6 \mathrm{~h}$ and the total amount of tramadol consumed $24 \mathrm{~h}$ were lower in the FAS group than in the G group and we also observed that the first analgesic requirement was later. There was no requirement for additional analgesia in the first $24 \mathrm{~h}$ in the FAS group; however, nine patients required additional analgesia in group G. Bromage scores were significantly higher in the FAS group at $0,1,6$, and $12 \mathrm{~h}$. The duration of operation and tourniquet was significantly longer in the $G$ group than in the FAS group.

The knee joint is innervated by the end branches of the femoral, sciatic, and obturator nerves ${ }^{10}$. In a metaanalysis of eight randomized controlled trials including 379 patients, it was reported that the addition of sciatic nerve block to femoral nerve block in TKA significantly reduces postoperative pain and opioid consumption ${ }^{11,12}$. USG guided anterior sciatic nerve block in addition to femoral nerve block can be safely applied in arthroscopic knee surgeries, knee surgeries, and in patients with high comorbidity, the application of other anesthesia methods is at high risk, and it has also been reported that this block provides effective postoperative analgesia ${ }^{13-15}$. In our study, we preferred the anterior sciatic nerve block owing to its ease of administration and better tolerability by patients, and this block does not require a special position, unlike other sciatic nerve block approaches.

The genicular nerve block is an up-to-date analgesia method used for chronic osteoarthritis, acute postoperative pain in TDA, and chronic knee pain ${ }^{8,9}$. In anatomical studies, reference points for anatomical relations of the genicular nerves with surrounding tissues and USG imaging were defined, and anatomical information was provided for proper needle placement in perioperative pain treatment 16 , 17. Genicular nerves, which are associated with knee pain, have been clinically proven in previous studies and have only been indicated as SMGS, SLGS, and IMGS16,18,19. Radiofrequency ablation or local anesthetic infiltration is generally applied to these nerves under the guidance of USG or fluoroscopy ${ }^{9,20}$. Similar to these studies, in the present study, we identified SMGN, SLGN, IMGN as target nerves.

Sotelo et $a .^{8}$ performed a two-part anatomical and clinical study. In the anatomical part, they reported the spread of contrast solution in computed tomography and surgical dissection after ultrasoundguided genicular nerve injections. In the clinical part, 12 patients who underwent TKA with spinal anesthesia, $4 \mathrm{~mL}$ of 1: 200,000 adrenaline solution with $0.25 \%$ isobaric bupivacaine was administered to the SMGN, SLGN, IMGN, and ILGN areas, USG before surgery. They reported that pain assessed using the numeric rating scale (NRS) mean was $2 \pm$ 1 , and additional analgesics (NSAIDs) required a patient rate of $42 \%$ after the termination of the subarachnoid block in the recovery room. They reported an NRS mean of $4 \pm 1$ and an additional analgesic (pethidine) required a patient rate of $33 \%$ at $12 \mathrm{~h}$. In addition, $92 \%$ of the patients were satisfied with the analgesic technique. In this study, the analgesic efficacy of the first $12 \mathrm{~h}$ was evaluated, and it was concluded that the genicular block is also clinically effective for acute pain. In the present study, the patients were followed up for a period of $24 \mathrm{~h}$ regarding PCA device use. VAS scores were significantly lower in the FAS group at 0,1 , and $6 \mathrm{~h}$. However, the mean VAS score was below 4 in the $G$ group. VAS scores at $12 \mathrm{~h}$ and $24 \mathrm{~h}$ were similar in both groups. Both methods were effective in controlling severe postoperative pain in TKA owing to low postoperative pain scores and high patient satisfaction. The frequency of postoperative 
complications did not increase due to increased opioid consumption in the PCA device.

Patient demand, bolus dose request, and total tramadol consumption were significantly higher in the $G$ group. However, in our study, the mean of tramadol consumption was lower than that reported in similar studies ${ }^{21,22}$. In the first $24 \mathrm{~h}$ of the postoperative period, there was no additional analgesic requirement in the FAS group, while nine patients in the $G$ group required additional analgesics. In the early postoperative period, a shorter tourniquet duration leads to less pain than a longer tourniquet duration $^{23}$. A longer duration of operation and tourniquet may cause increased postoperative pain scores and opioid consumption. In our study, the operation and tourniquet durations were significantly longer in the $\mathrm{G}$ group. We assume that the difference in tramadol consumption may be owing to the long operation and tourniquet durations of the $G$ group.

Hakkalamani et al. ${ }^{24}$ reported that patients who had FSA block for postoperative analgesia in TKA complained about the weight on their feet and the slow movement of their feet. The fact that the genicular nerve block does not cause motor block is one of the most important advantages of a genicular nerve block in ambulatory TKA. In our study, the motor block was evaluated using a Bromage scale for $24 \mathrm{~h}$, and motor block continued for $12 \mathrm{~h}$ postoperatively in the FAS group, while no motor block was observed in any patient in the G group.

There are some limitations to the present study. The main limitation was the lack of a control group in our study. Another limitation is that dynamic VAS scores are not evaluated. The fact that operation and tourniquet durations are not similar between the two groups can be considered a limitation.

Our study showed that ultrasound-guided femoral and sciatic nerve blocks were superior to the genicular nerve blocks in TKA. However, in the genicular block group, VAS scores were $<4$, and patient satisfaction and side effects were similar. Additionally, the genicular block doesn't causes motor block, which is a desirable feature. Given these results, we believe that a genicular block can be considered as an alternative.

Yazar Katkıları: Çalışma konsepti/Tasarımı: CY, ZGT; Veri toplama: ZGT, ÇB; Veri analizi ve yorumlama: DK, CK; Yazı taslağı: ZGT; Içeriğin eleștirel incelenmesi: ZGT, CBB; Son onay ve sorumluluk: ÇB, ZGT, CY, DK; Teknik ve malzeme desteği: -; Süpervizyon: DK; Fon sağlama (mevcut ise): yok.
Etik Onay: Bu calısma için Uludağ Üniversitesi Tip Fakültesi Klinik Araștırmalarl Etik Kurulundan 20.10.2021 tarih ve 2011/KAEK-26 sayılı kararı ile etik onay alınmıştır.

Hakem Değerlendirmesi: Dış bağımsız.

Çıkar Çatışması: Yazarlar çıkar çatışması beyan etmemişlerdir.

Finansal Destek: Yazarlar finansal destek beyan etmemişlerdir.

Author Contributions: Concept/Design : CY, ZGT; Data acquisition: ZGT, ÇB; Data analysis and interpretation: DK, CK; Drafting manuscript: ZGT; Critical revision of manuscript: ZGT, ÇB; Final approval and accountability: ÇB, ZGT, CY, DK; Technical or material support: -; Supervision: DK; Securing funding (if available): $\mathrm{n} / \mathrm{a}$

Ethical Approval: For this study, ethical approval was obtained from the Ethics Committee of Uludağ University Faculty of Medicine Clinical Research by decision No. 2011/KAEK-26 dated 20.10.2021.

Peer-review: Externally peer-reviewed.

Conflict of Interest: Authors declared no conflict of interest.

Financial Disclosure: Authors declared no financial support

\section{REFERENCES}

1. Brandt KD, Dieppe P, Radin EL. Etiopathogenesis of osteoarthritis. Rheum Dis Clin North Am. 2008;34:531-59.

2. Arden N, Nevitt MC. Osteoarthritis: epidemiology. Best Pract Res Clin Rheumatol. 2006;20:3-25.

3. Grosu I, Lavand'homme P, Thienpont E. Pain after knee arthroplasty: an unresolved issue. Knee Surg Sports Traumatol Arthrosc. 2014;22:1744-58.

4. Ilfeld BM, Mariano ER, Girard PJ, Loland VJ, Meyer SR, Donovan JF et al. A multicenter, randomized, triple-masked, placebo-controlled trial of the effect of ambulatory continuous femoral nerve blocks on discharge-readiness following total knee arthroplasty in patients on general orthopaedic wards. Pain. 2010;150:477-84.

5. Korean Knee Society. Guidelines for the management of postoperative pain after total knee arthroplasty. Knee Surg Relat Res. 2012;24:201-7.

6. Güler G, Atıcı S, Kurt E, Karaca S, Yılmazlar A. Current approaches in hip and knee arthroplasty anaesthesia. Turk J Anaesthesiol Reanim. 2015;43:188-95.

7. Dong CC, Dong SL, He FC. Comparison of adductor canal block and femoral nerve block for postoperative pain in total knee arthroplasty: a systematic review and meta-analysis. Medicine. 2016;95:e2983.

8. Sotelo VG, Maculé F, Minguell J, Bergé R, Franco C, Sala-Blanch X. Ultrasound-guided genicular nerve block for pain control after total knee replacement: Preliminary case series and technical note. Rev Esp Anestesiol Reanim. 2017;64:568-76.

9. Qudsi-Sinclair S, Borrás-Rubio E, Abellan-Guillén JF, Padilla Del Rey ML, Ruiz-Merino G. A Comparison of genicular nerve treatment using either radiofrequency or analgesic block with corticosteroid for pain after a total knee arthroplasty: a double-blind, randomized clinical study. Pain Pract. 2017;17:578-88.

10. Hadžić A, Vloka JD, Kuroda MM, Koorn R, Birnbach DJ. The practice of peripheral nerve blocks in the United States: a national survey. Reg Anesth Pain Med. 1998;23:241-6. 
11. Abdallah FW, Brull R. Is sciatic nerve block advantageous when combined with femoral nerve block for postoperative analgesia following total knee arthroplasty? A systematic review. Reg Anesth Pain Med. 2011;36:493-8.

12. Cook P, Stevens J, Gaudron C. Comparing the effects of femoral nerve block versus femoral and sciatic nerve block on pain and opiate consumption after total knee arthroplasty. J Arthroplasty. 2003;18:583-6.

13. Weihrauch JO, Jehmlich M, Leischik M, Hopf HB. Are peripheral nerve blocks of the leg (femoralis in combination with anterior sciatic blockade) as sole anaesthetic technique an alternative to epidural anaesthesia. Anasthesiol Intensivmed Notfallmed Schmerzther. 2005;40:18-24.

14. Pandin P, Vancutsem N, Salengros JC, Huybrechts I, Vandesteene A. The anterior combined approach via a single skin injection site allows lower limb anesthesia in supine patients. Can J Anaesth. 2003;50:801-4.

15. Eltohamy SA. Ultrasound guided two-in-one technique for sciatic and femoral nerve block in below knee surgery: Comparison between two entry points. Egyptian Journal of Anaesthesia. 2012;28:261-7.

16. Yasar E, Kesikburun S, Kılıç C, Güzelküçük Ü, Yazar F, Tan AK. Accuracy of ultrasound-guided genicular nerve block: a cadaveric study. Pain Physician. 2015;18:E899-904.

17. Tran J, Peng PWH, Lam K, Baig E, Agur AMR, Gofeld M. Anatomical study of the innervation of anterior knee joint capsule: implication for imageguided intervention. Reg Anesth Pain Med. 2018:43:407-14

18. Choi WJ, Hwang SJ, Song JG, Leem JG, Kang YU,
Park PH et al. Radiofrequency treatment relieves chronic knee osteoarthritis pain: a double-blind randomized controlled trial. Pain. 2011;152:481-7.

19. Franco CD, Buvanendran A, Petersohn JD, Menzies $\mathrm{RD}$, Menzies LP. Innervation of the anterior capsule of the human knee: implications for radiofrequency ablation. Reg Anesth Pain Med. 2015;40:363-8.

20. Santana Pineda MM, Vanlinthout LE, Moreno Martín A, van Zundert J, Rodriguez Huertas F, Novalbos Ruiz JP. Analgesic effect and functional improvement caused by radiofrequency treatment of genicular nerves in patients with advanced osteoarthritis of the knee until 1 year following treatment. Reg Anesth Pain Med. 2017;42:62-8.

21. Mudumbai SC, Kim TE, Howard SK, Workman JJ, Giori N, Woolson S et al. Continuous adductor canal blocks are superior to continuous femoral nerve blocks in promoting early ambulation after TKA. Clin Orthop Relat Res. 2014;472:1377-83.

22. Memtsoudis SG, Yoo D, Stundner $O$ et al. Subsartorial adductor canal vs femoral nerve block for analgesia after total knee replacement. Int Orthop. 2015:4:673-80.

23. Vaishya R, Agarwal AK, Vijay V, Tiwari MK. Short term outcomes of long duration versus short duration tourniquet in primary total knee arthroplasty: A randomized controlled trial. J Clin Orthop Trauma. 2018;9:46-50.

24. Hakkalamani S, Carroll AF, Ford C, Parkinson RW. Femoral versus combined femoral and sciatic nerve block in total knee replacement: A prospective comparative study. J Bone Joint Surg Br. 2019;91(Suppl 1):141. 